\title{
$\alpha$-GALACTOSIDASE OF ASPERGILLUS NIGER: PURIFICATION AND PROPERTIES
}

\author{
N.V.Borzova, L.D.Varbanets \\ D.K. Zabolotny Institute of Microbiology and Virology \\ of NAS of Ukraine \\ 154, Zabolotny St., Kyiv MSP D03680, Ukraine \\ e-mail: varbanets@serv.imv.kiev.ua
}

Highly purified $\alpha$-galactosidase (specific activiys $25 \mathrm{U} / \mathrm{mg}$ protein) has been isolated from the cultural liquid of Aspergillus niger. The enzyme is thermo- and $\mathrm{pH}$-stable, with $\mathrm{pH}$-optimum 4.1, and temperature optimum $60^{\circ} \mathrm{C} . \mathrm{K}_{\mathrm{m}}$ and $\mathrm{V}_{\max }$ for nitrophenyl substrate was shown to be $1.19 \mathrm{mM}$ and $25 \mu \mathrm{mol} / \mathrm{min} / \mathrm{mg}$ protein, respectively. $\alpha$-Galactosidase was inhibited by the product of reaction $D$-galactose $\left(K_{i}-6.2 \times 10^{-2} M\right)$. The enzyme displayed narrow specificity towards glycon. It proved to be metal-independent. The active center of the enzyme contains the carboxylic group of the $\mathrm{C}$-terminal aminoacid and imidazole group of histidine.

Key words: $\alpha$-galactosidase, Aspergillus niger, physicochemical properties, kinetic parameters, active center.

\section{$\alpha$-ГАЛАКТОЗИДАЗА ASPERGILLUS NIGER: ОЧИСТКА I ВЛАСТИВОСТІ}

Отримано високоочищений препарат $\alpha$-галактозидази із культуральної рідини Aspergillus niger з питомою активністю 25 Од/мг білка. Препарат є термо- та $\mathrm{pH}$-стабільним, $\mathrm{pH}$-оптимум - 4.1, температурний оптимум $-60^{\circ} \mathrm{C} . \mathrm{K}_{\mathrm{m}}$ та $\mathrm{V}_{\max }$ для n-нітрофенільного субстрату становлять 1.19 мМ і 25 мкмоль/хв/мг білка, відповідно. $\alpha$-Галактозидаза інгібується продуктом реакції, а саме D-галактозою, $\mathrm{K}_{\mathrm{i}}-6.2 \times 10^{-2} \mathrm{M}$. Отриманий фермент проявляє вузьку специфічність щодо глікону. Фермент $€$ металонезалежним. В активному центрі молекули присутня карбоксильна група С-кінцевої амінокислоти та імідазольна група гістидину.

Ключові слова: $\alpha$-галактозидаза, Aspergillus niger, фізико-хімічні властивості, кінетичні параметри, активний центр. 


\section{INTRODUCTION}

Enzymatic preparations of microbial origin are widely used as analyitical reagents in the research, as well as for the diagnostics in clinics. Enzymatic assay methods possess high specificity and susceptibility that significantly overcome physical and chemical methods and, thus, promote further investigations. For that reason, the targeted search for highly productive microorganism strains needed to solve technological problems involving production of the enzymatic preparations with various characteristics have been rapidly developing.

Hydrolytic enzymes (O-glycoside-hydrolases), that are capable of catalysing O-glycoside bonds in glycosides, oligo- and polysaccharides, glycolipids and other glycoconjugates, have been drawing researchers attention. These enzymes participate in a series of key metabolic processes. The peculiarity of such enzymes is their absolute specificity towards bond configuration that should be cleaved. Glycosidases can be also used for investigation of the structure of glycan constituent in complex glycopolymeres [22], since the enzymatic cleavage of the glycoside bond provides an exclusively mild and highly specific procedure. $\alpha$-Galactosidase ( $\alpha$-D-galactohydrolase, 3.2.1.22) shows high specificity to terminal $\alpha$-bound D-galactose residues of natural and synthetic glycoconjugates.

Aspergillus niger is producing wide pattern of extracellular enzymes, specific toward plant oligo- and polysaccharides and hydrolysing the $\alpha$ - and $\beta$-bound galactose. This microorganism is also capable of producing $\alpha$-galactosidases with varying specificity dependent on the used substrate.

The aim of this work was to obtain highly purified preparation of the extracellular $\alpha$-galactosidase of $A$. niger, characterization of its physico-chemical, and catalytic properties, and specificity of action that could help in grounding practical employment of the enzyme.

\section{MATERIALS AND METHODS}

Aspergillus niger Thom strain (185), used in the study was kindly provided by Shkol'ny O.T. and Zhdanova N.M. (Collection of living cultures of D.K.Zabolotny IMB NAS of Ukraine).

Culturing the micromycetes was performed intermittently in shaker conditions (220 rpm) at $25 \pm 1^{\circ} \mathrm{C}$ in the medium composed of $(\mathrm{g} / \mathrm{l})$ : soybean flour $-25.0,\left(\mathrm{NH}_{4}\right)_{2} \mathrm{SO}_{4}-$ 0.8 (or pepton - 7.5), $\mathrm{KH}_{2} \mathrm{PO}_{4}-2.0, \mathrm{CaCl}_{2}-0.3, \mathrm{MgSO}_{4} \times 7 \mathrm{H}_{2} \mathrm{O}-0.3$.

Appropriate synthetic substrates were used upon examining the glycosidase activities: $p$-nitrophenyl-2-acetamido-2-deoxy- $\alpha$-D-galactopyranoside, $p$-nitrophenyl2-acetamido-2-deoxy- $\beta$-D-galactopyranoside, $p$-nitrophenyl-2-acetamido-2-deoxy- $\alpha$ and $\beta$-D-glucopyranoside („Koch-Light”, Great Britain), p-nitrophenyl- $\alpha$ - and $\beta$-D-galactopyranoside, $p$-nitrophenyl- $\alpha$ - and $\beta$-D-glucopyranoside, $p$-nitrophenyl- $\beta$-D-xylopyranoside, $p$-nitrophenyl- $\alpha$ - and $\beta$-D-mannopyranoside, $p$-nitrophenyl- $\alpha$-D-fucopyranoside („Sigma”, USA). To measure enzymatic activities, $0.1 \mathrm{ml}$ of enzyme solution was mixed with $0.2 \mathrm{ml} 0.1 \mathrm{M}$ phosphate-citrate buffer (FCB) $\mathrm{pH} 5.2$ and $0.1 \mathrm{ml} 0.01$ substrate solution in FCB. The reaction mixture was incubated at $37^{\circ} \mathrm{C}$ for $10 \mathrm{~min}$. The reaction was stopped by adding $2 \mathrm{ml}$ of $1 \mathrm{M}$ sodium bicarbonate. In control, the same components were added, but in the inverse order. The amount of nitrophenol hydrolysed was measured colorimetrically at $400 \mathrm{~nm}$ [5].

Upon evaluating $\alpha$-galactosidase activity towards natural substrates, the amount of glucose (equivalent to galactose amount), released as a result of melibiose hydrolysis, was estimated by glucoseoxidase procedure [5], and the amount of galactose resultant 
from the raffinose hydrolysis - by Somogyi method [20]. The invertase activity was measured by glucoseoxidase procedure [5]. The proteolytic activity was estimated according to Anson, as modified by Petrova [18]. As a unit of $\alpha$-galactosidase activity, as well as other glycosidases, was taken such amount of the enzyme that catalysed hydrolysis of $1 \mu \mathrm{m}$ of substrate per minute under standard experimental conditions $\left(37^{\circ} \mathrm{C}, \mathrm{pH} 5.2\right)$. Protein concentration was determined by the method of Lowry et al. [16], nucleic acids - by Spirin [21], and neutral sugars concentration - by Dubois et al. [10]. The identification of neutral sugars was carried out as polyol acetates by means of gas-liquid chromatography using Chrom-5 (Czech Republic) [1]. Aminoacid and hexosamine contents were measured by the aminoacid analyzer Hitachi KLA-5 (Japan).

Procedure of enzyme isolation:

a) Cultural fluid was subjected to $30 \%$ ammonium sulphate saturation under $\mathrm{pH}$ control. The mixture was incubated at $4^{\circ} \mathrm{C}$ for $2 \mathrm{~h}$ and centrifugated at $5000 \mathrm{rpm}$ for $30 \mathrm{~min}$. The precipitate was discarded, and the supernantant was treated with ammonium sulphate to achieve its final concentration of $90 \%$ saturation. The mixture was incubated at $4^{\circ} \mathrm{C}$ for $6 \mathrm{~h}$ and centrifugated under the above noted conditions. The precipitate was removed and dissolved in 3-fold volume of $3 \mathrm{M}$ ammonium sulphate supplemented with $0.01 \mathrm{M}$ of sodium azide for preservation;

b) Cooled to $4^{\circ} \mathrm{C}$ cultural medium was slowly mixed by stirring with two volumes of cooled aceton and ethanol $\left(-20^{\circ} \mathrm{C}\right)$. The mixture was incubated for $1.5-2 \mathrm{~h}$ at $4^{\circ} \mathrm{C}$ and centrifugated at $5000 \mathrm{rpm}$ for $30 \mathrm{~min}$. The supernatant was discarded and the precipitate was washed up with dissolvent and dried at room temperature.

Enzyme purification using neutral and charged TSK-gels. To obtain highly purified enzyme preparation, gel-filtration and ion-exchange chromatography were used. Gelfiltration was run on $2.5 \times 90 \mathrm{~cm}$ column packed with neutral TSK-gel Toyopearl HW-60, Toyo Soda (Japan), equilibrated with $0.01 \mathrm{M}$ phosphate buffer, $\mathrm{pH}$ 7.0. Precipitate resultant from the fractionation with ammonium sulphate, was centrifuged, dissolved in 1.5 volume of $0.1 \mathrm{M}$ phosphate buffer, $\mathrm{pH}$ 7.0. The resultant preparation (200$300 \mathrm{mg}$ of protein) was applied to the column, eluted by the same buffer at $90 \mathrm{ml} / \mathrm{h}$ rate. Protein content was registered on SF-26 at $280 \mathrm{~nm}$. Fractions exhibiting $\alpha$-galactosidase activity were collected and concentrated $(\approx 5$-fold) by evaporating under vacuum.

The resultant preparation (4-5 ml, 60-70 mg of protein) was applied to $3 \times 35 \mathrm{~cm}$ column packed with Fractogel DEAE-650-s, Merck (Germany) equilibrated with $0.01 \mathrm{M}$ Tris- $\mathrm{HCl}$ buffer, $\mathrm{pH}$ 7.8. The elution was performed by $\mathrm{NaCl}$ linear gradient $(0-0.4 \mathrm{M}$, $200 \mathrm{ml}$ ) at $24 \mathrm{ml} / \mathrm{h}$ rate. Enzymaticaly active fractions were removed, dialyzed against distilled water, and freeze dried.

Rechromatography was run on $1.3 \times 52 \mathrm{~cm}$ column packed with Sepharose $6 \mathrm{~B}$ and equilibrated with $0.1 \mathrm{M}$ phosphate buffer, $\mathrm{pH} 6.0$. The elution was performed by the same buffer supplemented with $0.1 \mathrm{M} \mathrm{NaCl}$ at $60 \mathrm{ml} / \mathrm{h}$ rate. $1 \mathrm{ml}$ of the preparation (20 $\mathrm{mg}$ of protein) was applied to the column.

SDS-PAAG-electrophoresis was carried, as described by Laemmly [15]. Enzyme preparations were dissolved in sample buffer $(0.5 \mathrm{M}$ Tris- $\mathrm{HCl}, \mathrm{pH} 8.8,2$-mercaptoethanol, $10 \%$ SDS, $20 \%$ glycerine and $0.001 \%$ bromphenol blue), boiled for $1 \mathrm{~min}$, and applied into gel (50-100 $\mu \mathrm{g}$ per well). Electrophoresis was run in $5 \%$ concentrating and $12 \%$ resolving PAAG at $30 \mathrm{~mA}$. The gels were stained with Coomassie G-250 for protein visualization.

Determination of the enzyme molecular mass was performed by gel-filtration [3] on $1.3 \times 50 \mathrm{~cm}$ column packed with Sepharose $6 \mathrm{~B}$ and equilibrated with $0.01 \mathrm{M}$ phosphate buffer, pH 6.0. $1 \mathrm{ml}$ of the enzyme solution $(10 \mathrm{mg})$ was applied after an 
increasing of the solution density by sucrose (final concentration $0.5 \mathrm{M}$ ). The elution was run by the same buffer supplemented with $0.1 \mathrm{M} \mathrm{NaCl}$ at $0.3 \mathrm{ml} / \mathrm{min}$ rate. Standard curve for molecular mass calculations was built by using of high molecular weight protein markers, Pharmacia (Sweden), aldolase (158 kDa), catalase (232 kDa), ferritin (440 kDa), and thyreoglobulin (669 kDa).

An assessment of optimum $\mathrm{pH}$ and temperature conditions of $\alpha$-galactosidase activity was carried out within $20^{\circ} \mathrm{C}$ and $70^{\circ} \mathrm{C}$ temperature range and 2.0 and $8.0 \mathrm{pH}$ range (the latter was achieved by $0.01 \mathrm{M} \mathrm{FCB}$ ).

The enzyme thermostability was evaluated at $37^{\circ} \mathrm{C}$ (exposition time $90 \mathrm{~min}$ ), $\mathrm{pH}$ stability - at pH 6.0 and 7.0 (exposition time $24 \mathrm{~h}$ ). Following termination of the enzyme exposition to an appropriate condition factor, $0.1 \mathrm{ml}$ enzyme aliquotes were removed, supplemented with $0.2 \mathrm{ml}$ of FCB, pH 5.2, and $0.1 \mathrm{ml}$ of synthetic substrate solution was added. The enzymatic activity was measured, as described above.

Measurement of kinetic parameters of $\alpha$-galactosidase reaction was performed in reaction mixture containing $0.1 \mathrm{ml}$ of the substrate in a proper concentration $(0.1-$ $4.0 \mu \mathrm{g} / \mathrm{ml}$ ) in $0.01 \mathrm{M} \mathrm{FCB}, \mathrm{pH} 5.2$, and $0.1 \mathrm{ml}$ of the enzyme solution (final concentration $0.5 \mathrm{mg} / \mathrm{ml}$ ). For each substrate concentration (S), the reaction was performed at $37^{\circ} \mathrm{C}$, as described above. The maximum rate $\left(\mathrm{V}_{\max }\right)$ and Michaelis constant $\left(\mathrm{K}_{\mathrm{m}}\right)$ were determined, according to Lineweaver-Burk dependence of the enzyme reaction rate on the substrate concentration [12].

Effect of the carbohydrates, cations, anions and other chemical agents on the enzyme activity was studied using purified $\alpha$-galactosidase preparations with specific activity $5 \mathrm{U} / \mathrm{mg}$ of protein (protein content $-0.49 \mathrm{mg} / \mathrm{ml}$ ). Cations were used as sulphates, anions - as potassium or sodium salts in final concentration $10^{-3} \mathrm{M}$, and carbohydrates $-10^{-2}$ and $10^{-3} \mathrm{M}$. For inhibitory analysis, specific chemical agents were used: ethylenediaminetetraacetate (EDTA), o-phenantroline, sodium azide, sodium arsenite, sodium sulfite, $\beta$-mercaptoethanol, L-cysteine, dithiothreitol, $p$-chloromercuribenzoate (final concentration $10^{-3} \mathrm{M}$ ).

Incubation of the enzyme with a corresponding agent was performed at $20^{\circ} \mathrm{C}$ for $1 \mathrm{~h} .0 .1 \mathrm{ml}$ aliquotes containing $49 \mu \mathrm{g}$ protein were removed in 15, 30 and $90 \mathrm{~min}$ to measure glycosidase activity in $0.01 \mathrm{M} \mathrm{FCB}$ at $\mathrm{pH} 5.2$.

Kinetic analysis of the effect of metal ions and specific chemical agent upon $\alpha-$ galactosidase activity was carried out, as recommended by Dixon and Webb [9] and following to Lineweaver-Burk [12].

Determination of $\mathrm{pK}$ for dissociating groups involved in hydrolysis of appropriate substrates was performed, as described by Dixon and Webb [9], and dependence of the reaction rate upon $\mathrm{pH}$, as described in [14].

Ionization heat of the catalytically active groups was calculated by Vant-Hoff equation:

$$
\Delta \mathrm{H}=2,303 \mathrm{R}\left(\mathrm{pK}_{1}-\mathrm{pK}_{2}\right) /\left(\mathrm{T}_{1} \mathrm{~T}_{2} /\left(\mathrm{T}_{2-}-\mathrm{T}_{1}\right)\right),
$$

where $\mathrm{H}$ is the ionization heat of the catalytically active group; $\mathrm{R}$ - gas constant that equals $8.36 \mathrm{~J} / \mathrm{mol}^{-1} ; \mathrm{pK}_{1}, \mathrm{pK}_{2}$ - constants of ionization at temperatures $\mathrm{T}_{1}$ and $\mathrm{T}_{2}$, respectively. $\mathrm{pK}_{1}$ and $\mathrm{pK}_{2}$ values were found from the curves $\mathrm{V}=f(\mathrm{pH})$ built within temperature range of $5-50^{\circ} \mathrm{C}$.

Photooxidation was carried out upon various $\mathrm{pH}$ and temperature values. As a source of light, there filament lamp (glow-lamp, $200 \mathrm{wt}$ ) with red filter $15 \mathrm{~cm}$ over the solution surface was used. As a photosensibilisator, $5 \times 10^{-6} \mathrm{M}$ methylene blue was employed. As controls, samples to harbor the same amount of photosensibilisator but kept in darkness, as well as specimen to be illuminated by the same source of light lacking the stain, were used. 


\section{RESULTS AND DISCUSSION}

Isolation and purification of $\alpha$-galactosidase. Production of highly purified enzyme preparations provides an opportunity for their broad employment in enzymotherapy, biotransformation of erythrocytes of groups $A(I I)$ and $B($ III), development of diagnostic test-systems.

During isolation of $\alpha$-galactosidase from $A$. niger strain 185 , the major criteria for the procedure efficiency were: a) specific activity of the preparation; b) maximum outcome of the activity; c) low content of impurities, for example, nucleic acids, since elimination of the latter at the initial stage would allow to achieve high degree of purification at the final steps. The isolation of the enzyme was performed by three different ways: 1) fractionation with ammonium sulphate (30-90\% of saturation); 2) precipitation with ethanol; 3) precipitation with aceton. Each of these ways was shown to be rather efficient, especially in the case of further freeze drying of the preparation. However, while the ammonium sulphate fractionation is applicable for enzyme production in the laboratory conditions, glycosidase precipitation by ethanol is more technological for industry, since that ensures higher yield of the enzyme by its activity and fulfill other requirements of industry.

Micromycetes cultural liquid, particularly that of $A$. niger, was reported to exhibit broad pattern of various glycosidase activities [13]. This is due to the fact that natural environment for micromycetes contains plant remains rich in oligo- and polysaccharides, as well as complex carbohydrate-anchoring compounds, and, thus, procedured glycosidases allow the micromycetes using various carbon sources. However, this property of the fungi cultures also makes more complicated isolation and purification of the individual glycosidases. In cultural liquid of strain 185, in addition to $\alpha$-galactosidase activity, $\alpha-\mathrm{N}$-acetylgalactosaminidase, $\beta-\mathrm{N}$-acetylgalactosaminidase, $\beta$-galactosidase, $\beta-\mathrm{N}$-acetylglucosaminidase, and $\beta$-glucosidase activities are present. We partially succeeded to get rid of those impurities by enzyme fractionation with ammonium sulphate, although the obtained preparation has still been displaying these additional activities. Table 1 summarizes steps of the enzyme isolating and purificating from $A$. niger 185 cultural liquid. It includes fractionation with ammonium sulphate, gel-filtration, ion-exchange chromatography and chromatography on Sepharose $6 \mathrm{~B}$. As a result, we got 600 -fold purification with $28 \%$ outcome of $\alpha$-galactosidase and $\alpha-\mathrm{N}$-acetylgalactosaminidase activities -25 and $10.5 \mathrm{U} / \mathrm{mg}$ of protein, respectively. These values correspond to the recognized $\alpha$-galactosidase industrial producer and their preparations. The enzyme preparation didn not possess other glycosidase and proteolytic activities.

Table 1. Purification of $\alpha$-galactosidase from A. niger 185

\begin{tabular}{l|c|c|c|c|c|c|c}
\hline Steps of purification & $\begin{array}{c}\text { Total protein, } \\
\mathrm{mg}\end{array}$ & $\begin{array}{c}\text { Total } \\
\text { activity, } \mathrm{U}\end{array}$ & Yield, \% & $\begin{array}{c}\text { Specific } \\
\text { activity, } \\
\mathrm{U} / \mathrm{mg}\end{array}$ & $\begin{array}{c}\text { Degree of } \\
\text { purification }\end{array}$ & $\begin{array}{c}\text { Nucleic acid } \\
\text { content, mg }\end{array}$ & $\begin{array}{c}\text { Carbohydrate } \\
\text { content, mg }\end{array}$ \\
\hline $\begin{array}{l}\text { 1. Cultural fluid } \\
\text { 2. Fractionation with } \\
\text { ammonium sulphate }\end{array}$ & 8,000 & 5,281 & 81.41 & 0.66 & 3.5 & 57.4 & 1,265 \\
\hline $\begin{array}{l}\text { 3. Gel-filtration on } \\
\text { Toyopearl HW-60 }\end{array}$ & 800 & 4,582 & 70.63 & 5.73 & 35 & 28 & 500 \\
\hline $\begin{array}{l}\text { 4. Anion exchange } \\
\text { chromatography } \\
\text { on Fractogel } \\
\text { DEAE-650-s }\end{array}$ & 112 & 2,450 & 37.76 & 21.9 & 250 & 0 & 102 \\
\hline $\begin{array}{l}\text { 5. Chromatography } \\
\text { on Sepharose 6B }\end{array}$ & 46 & 1,163 & 28.74 & 25.3 & 600 & 0 & 2.52 \\
\hline
\end{tabular}


Characterisation of the enzyme preparation. The resultant enzyme preparation was shown to be homogenous as judged by gel-filtration using Sepharose 6B and its molecular mass constituted $430 \mathrm{kDa}$. The enzyme was sensitive to the effect of such denaturating agents as carbamide and guanidine hydrochloride in concentrations 1.6 and $0.8 \mathrm{M}$, respectively (Fig. 1). Such behavior might predict subunit structure of the enzyme molecule, that is typical for bacterial glycosidases, although it was also reported for $\alpha$-galactosidases of $C$. cladosporium and $A$. tamarii $[4,6]$. That suggestion is also in agreement with the results of electrophoresis in SDS-PAAG that demonstrated two protein bands: major one at $70 \mathrm{kDa}$; and minor one at $100 \mathrm{kDa}$ (Fig. 2). The enzyme appeares to be functioning in the oligomeric state since individual subunits failed to display any activity.

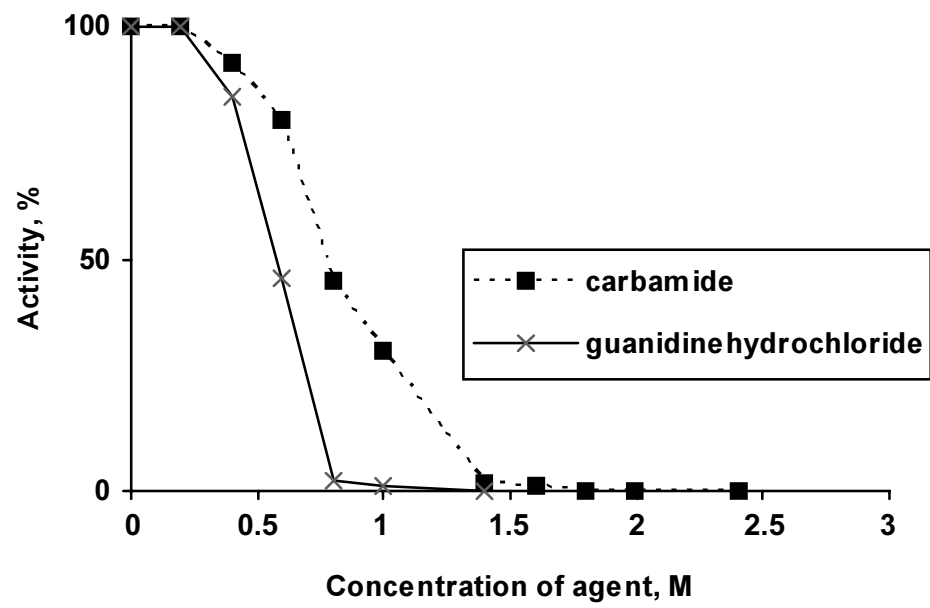

$\begin{array}{llll}M & 1 & 2 & 3\end{array}$
Fig 1. Dependence of $\alpha-g a-$ lactosidase activity on the effect of denaturating agent

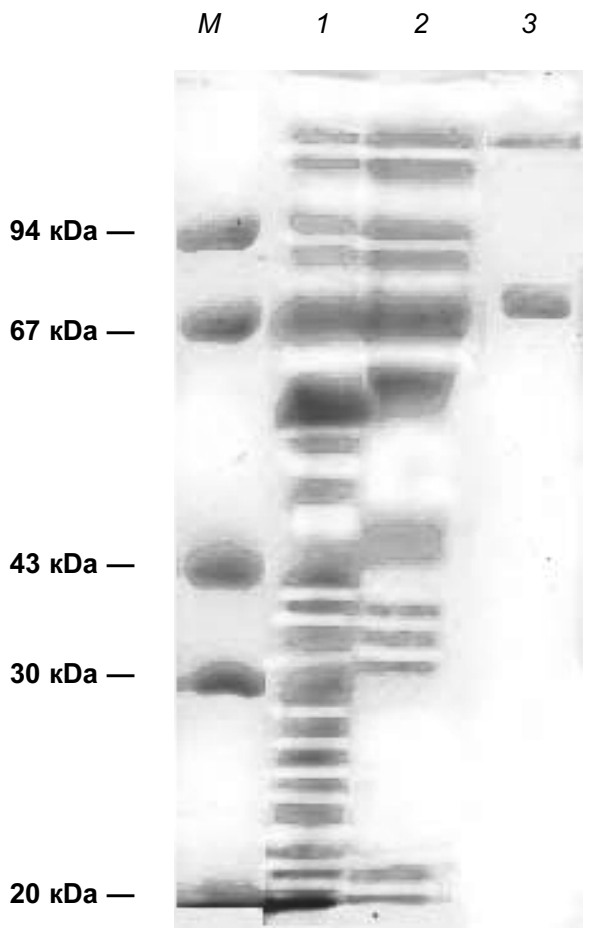

Fig. 2. Electrophoresis of $\alpha$-galactosidase preparation from $A$. niger 185 at various steps of purification: 1) culture liquid;

2) after gel-filtration on the TSK-gel HW-60;

3) after chromatography on Sepharose 6B;

M) markers of protein molecular mass 
Study of the aminoacid composition of the obtained preparation showed that the amount of hydrophobic aminoacids is about $30 \%$ of their total number. The enzyme molecule also contains $20 \%$ acid aminoacids (Table 2). Similar acid/basic aminoacids ratio was found in the majority of known $\alpha$-galactosidases [21]. The enzyme molecule contains carbohydrate component built of both uncharged monosaccharides - mannose and galactose $(5 \%)$, and charged ones - glucosamine $(2.6 \%)$, as well as by two unidentified aminosugars (2.1 and 2.5\%). Similar carbohydrate composition is characteristic for $\alpha$-galactosidase of $A$. tamarii [6]. It should be noted that microbial $\alpha$-galactosidases are distinguished by a considerable content of carbohydrates (up to $30-50 \%$ ).

Table 2. Aminoacid composition of $\alpha$-galactosidase from A. niger 185

\begin{tabular}{l|c|c}
\hline \multicolumn{1}{c|}{ Aminoacid } & \% on total peak & Residue per molecule \\
\hline Aspartic acid & 8.7 & 58 \\
\hline Threonine & 6.6 & 36 \\
\hline Serine & 10.0 & 46 \\
\hline Glutamic acid & 9.8 & 68 \\
\hline Proline & 0.5 & 18 \\
\hline Glycine & 14.8 & 38 \\
\hline Alanine & 10.8 & 46 \\
\hline Valine & 5.1 & 30 \\
\hline Isoleucine & 3.6 & 24 \\
\hline Leucine & 9.6 & 48 \\
\hline Tyrosine & 0.4 & 2 \\
\hline Phenylalanine & 3.7 & 24 \\
\hline Histidine & 1.9 & 12 \\
\hline Ornithine & 0.5 & 2 \\
\hline Lysine & 4.3 & 26 \\
\hline Arginine & 2.5 & 14 \\
\hline Glucosamine & 2.6 & 20 \\
\hline $\boldsymbol{X}^{*}$ & 2.1 & 16 \\
\hline $\boldsymbol{H}^{*}$ & 2.5 & 14 \\
\hline Total of & 100 & 542 \\
\hline
\end{tabular}

* unidentified aminosugars

Physico-chemical and catalytic properties of $\alpha$-galactosidase. Thermo- and $\mathrm{pH}-$ optima of hydrolysis of the synthetic substrate $\mathrm{p}$-nitrophenyl-N-acetyl- $\alpha$-D-galactopyranoside by enzyme preparation from the $A$. niger 185 were at $60^{\circ} \mathrm{C}$ and $\mathrm{pH} 3.5$ and 4.1 , respectively. However, within the $\mathrm{pH}$ range from 3.0 to 7.0 and at $37^{\circ} \mathrm{C}$ up to $70 \%$ of maximum activity was observed. The enzyme was stable within $\mathrm{pH}$ range between 3.0 and 7.0 and at $37^{\circ} \mathrm{C}$ for $90 \mathrm{~min}$. There were no indications of $\alpha$-galactosidase degradation during its storage in $3 \mathrm{M}$ ammonium sulphate solution for 2 years and its storage as freeze dried preparation for 6 months at $4^{\circ} \mathrm{C}$. High stability of the enzyme preparation could be caused by both a considerable content of hydrophobic aminoacids and presence of the carbohydrate component.

The evaluation of catalytic properties of the enzyme preparation showed that the synthetic nitrophenyl substrate competitively inhibited $A$. niger $185 \alpha$-galactosidase. These data correspond to the result of study of other $\alpha$-galactosidases. The LineweaverBurk approach demonstrated that $\alpha$-galactosidase activity of $A$. niger 185 is competitively inhibited by the product of reaction - D-galactose $\left(K_{i} 6.2 \times 10^{-2} M\right)$. 
$\alpha$-Galactosidase isolated from $A$. niger 185 displayed a narrow specificity with respect to glycon: its ability to detach glycosilic residues from the nitrophenyl substrates was restricted to $\alpha$-bound $\mathrm{N}$-acetylgalactosamine and $\mathrm{D}$-galactose $\left(\mathrm{K}_{\mathrm{m}} 1.25\right.$ and $1.19 \mathrm{mM}, \mathrm{V}_{\max } 10.5$ and $25 \mu \mathrm{mol} / \mathrm{min} / \mathrm{mg}$ protein, respectively). In addition, the enzyme preparation failed to hydrolyse such natural substrates as melibiose, raffinose and stachyose, that carry terminal $\alpha-1,6$-bond D-galactose. That might be caused by the enzyme's inability to interact with natural substrate, or to hydrolyse $\alpha-1,6$-bonds. Comparing our results to literature data, it looks that a general disadvantage shared by most glycosidases is resulted by their high affinity to aglycon portion of the synthetic substrate $[13,21]$. A recognized valuable property of the enzyme is its narrow specificity that allows them to be a convenient tool in structural investigations.

Examination of functional groups within the active center of $\alpha$-galactosidase. The analysis of kinetic curves for dependence of $\alpha$-galactosidase reaction rate upon $\mathrm{pH}$ revealed two groups that are ionized within the active center of the $A$. niger 185 enzyme with pK values 2.2 and 5.9, respectively (Fig. 3). According to Dixon and Webb [9], that corresponds to carboxylic group of C-terminal aminoacid and imidazolic group of histidine. An involvement of histidine imidazolic group and asparagine acid carboxylic group in the reaction catalyzed by $\alpha$-galactosidase, was reported for the enzymes isolated from the seeds of Vicia faba and mango [7, 8], as well as for some microbial $\alpha$-galactosidases [2, 21].

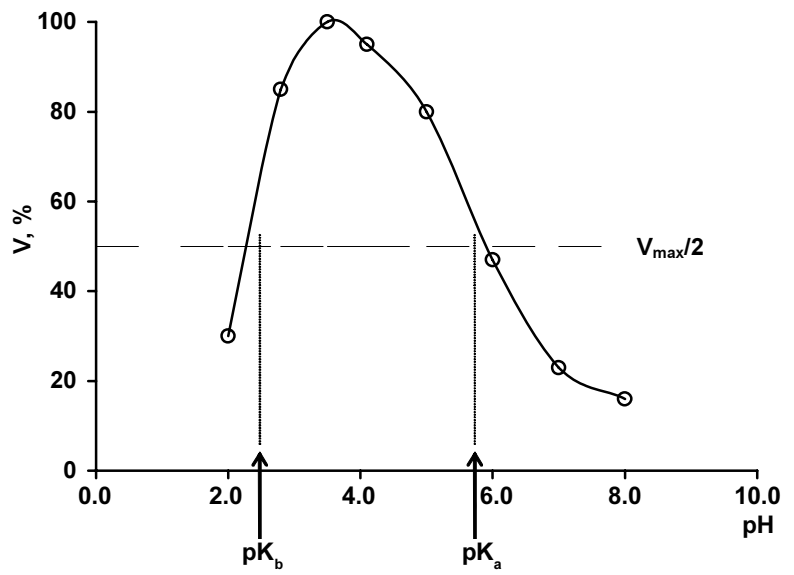

Fig. 3. Effect of $\mathrm{pH}$ on the activity of $\alpha$ galactosidase from $A$. niger 185. $\mathrm{V}$ - starting rate of reaction; $\mathrm{pK}_{\mathrm{b}}$ ionization constant of the enzyme's catalytic center active group for the ascending part of curve; $\mathrm{pK}_{\mathrm{a}}-$ ionization constant of the enzyme's catalytic center active group for the degressive part of curve

The presence of these specific groups was confirmed by defining the ionization heat. Deduced values of the ionization heat for the enzyme's active center correspond to previous data on availability of the catalytically important carboxylic and imidazole groups. In Table 3 the results of studying a shift of $\mathrm{pK}_{\mathrm{b}}$ and $\mathrm{pK}_{\mathrm{a}}$ upon temperature are presented. $\mathrm{pK}_{\mathrm{b}}$ shift is not so easy to be determined, since pK values vary within

Table 3. Effect of temperature on pK of $\alpha$-galactosidase active center from A. niger 185

\begin{tabular}{c|c|c}
\hline \multirow{2}{*}{ Temperature, $\mathbf{K}$} & \multicolumn{2}{|c}{ Changes in $\mathbf{p K}$} \\
\cline { 2 - 3 } & $\mathbf{p K}_{\mathbf{b}}$ & $\mathbf{p K}_{\mathbf{a}}$ \\
\hline 278 & 2 & 5.9 \\
\hline 283 & 2 & 6.1 \\
\hline 293 & 2.0 & 6.3 \\
\hline 303 & 2.1 & 6.4 \\
\hline 313 & 2.2 & 6.5 \\
\hline
\end{tabular}


a range of experimental uncertainty. This may suggest that such pK shift is caused namely by ionization of the carboxylic group. Calculations according to Vant-Hoff equation of the ionization heat $\Delta \mathrm{H}$ for $\mathrm{pK}_{\mathrm{b}}$ made up $6.5 \mathrm{~kJ} / \mathrm{mol}$, while for $\mathrm{pK}_{\mathrm{a}}-29.5 \mathrm{~kJ} / \mathrm{mol}$. These $\Delta \mathrm{H}$ values suggest that carboxylic and imidazole groups participate in the cleavage of glycosidic bonds. Thus, $\Delta \mathrm{H}$ value provides an important criterium for the enzyme active center specific group identification. According to [11], as soon as the value of pK group and the heat of its ionization are defined, one can judge for its chemical nature. The availability of histidine's imidazolic group was also supported by the results of our studies on photooxydizing in the presence of methylene blue that causes the disruption of imidazole heterocycle and enzyme inactivation (Fig. 4). We observed photoinactivation dependent on time and decline in $\mathrm{H}^{+}$-ions level in medium. Such behavior is typical for imidazole that serves as a „trap" for protons, and in case of the increased $\mathrm{pH}$ of medium it gives away the protons and proportionally raises the rate of group oxydizing.

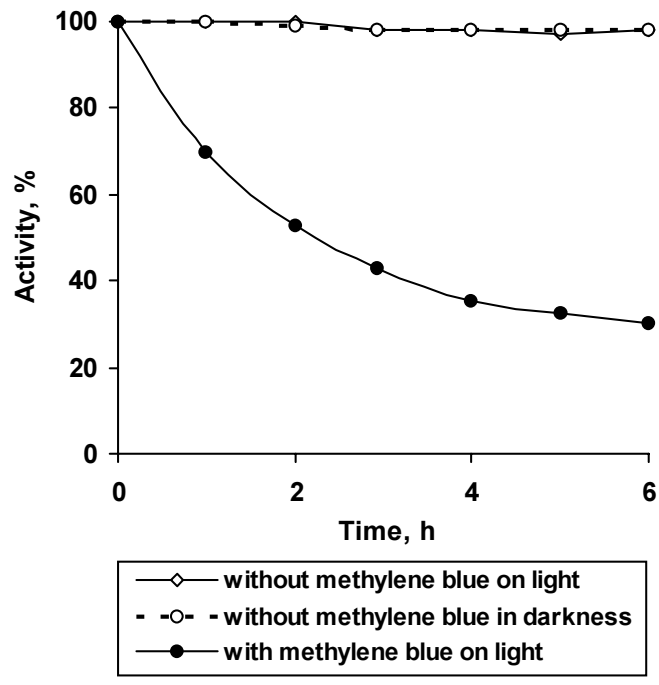

Fig. 4. Inactivation of the $\alpha$-galactosidase from A. niger 185 by photooxydizing, $\mathrm{pH} 4.0$

To reveal other functional groups affecting the catalysis inhibitory assay of $\alpha$ galactosidase reaction using ions of metals and anions, as well as the specific chemical agents was employed.

$\alpha$-Galactosidase refers to a group of enzymes, in which the presence of a metal is not a prerequisite for their activity. However, it may affect conformation of the enzyme molecule and render its active center to be more accessible for substrate with possible likewise changes in groups, that are far away from the active center. Examination of the effect of various metals on the activity of $A$. niger $185 \alpha$-galactosidase showed that most agents under study did not affect significantly its activity. $50 \%$ decrease in the $\alpha$-galactosidase activity was found upon germanium ions, while 2 -fold activation of $\alpha-\mathrm{N}$-acetylgalactosaminidase activity was observed here. The inhibitory effect towards $\alpha$-galactosidase was recorded for such metal ions, as $\mathrm{Ag}^{+}$, $\mathrm{Hg}^{2+}(100 \%)>\mathrm{Ge}^{4+}(50 \%)>\mathrm{Fe}^{3+}(30 \%)>\mathrm{Ni}^{2+}, \mathrm{Mn}^{2+}(15-20 \%)$. There was no influence on the activity of both enzymes of such cations as $\mathrm{Al}^{3+}, \mathrm{Zn}^{2+}, \mathrm{Mg}^{2+}, \mathrm{Cu}^{2+}, \mathrm{Ca}^{2+}, \mathrm{Na}^{+}, \mathrm{K}^{+}$, and $\mathrm{NH}_{4}^{+}$. Similar results were obtained for $\alpha$-galactosidases isolated from other micromycetes: Cephalosporium acremonium, Absidia ramosa, A. avamori [2, 17, 23]. It is believed that enzyme inhibition by ions of silver and mercury might result from their interaction with $\mathrm{SH}-$, carboxylic and imidazolic groups of the enzyme. 
Study of the effect of various anions towards the $\alpha$-galactosidase enzyme activity showed an inhibiting action of sulphite $(60 \%)$, tetraborate $(40 \%)$, and carbonate $(30 \%)$. The inhibiting effect of sulphite suggests the presence of SH-groups within the active center or around it. Insignificant inhibiting effect of other anions $\left(\mathrm{Cl}^{-}, \mathrm{I}^{-}, \mathrm{F}^{-}\right.$, $\mathrm{AsO}_{3}^{-2}, \mathrm{NO}_{3}^{-}, \mathrm{SO}_{4}^{-2}$ ) most likely appears to have been of nonspecific origin, since such suppression failed to raise with time and upon changes in effector level.

Study of the effect of such metal-binding agents as EDTA, o-phenantroline, and sodium azide showed (Table 4 ) that they did not affect the rate of $\alpha$-N-galactosaminidase and $\alpha$-galactosidase reactions. These results suggest that the catalysis by the $A$. niger 185 enzyme does not involve metal atoms, that is in agreement with literature data concerning $\alpha$-galactosidases isolated from other microorganisms [21].

The reagents reducing the disulphide groups did not affect $\alpha$-galactosidase activity (Table 4). Presumably, the enzyme molecule is devoid of the disulphide groups, or they are deeply immersed into the protein globule and, thus inaccessible to the action of these reagents.

Table 4. Effect of chemical reagents on activity of $\alpha$-galactosidase A. niger 185

\begin{tabular}{l|c|c}
\hline \multicolumn{1}{c|}{ Agent } & Concentration, $\mathbf{M}$ & $\begin{array}{c}\text { Residual activity of } \\
\alpha \text {-galactosidase, } \%\end{array}$ \\
\hline Control & & 100 \\
\hline EDTA & $10^{-3}$ & $85 \pm 4.0$ \\
\hline $\boldsymbol{p}$-Chloromercuribenzoate & $10^{-3}$ & $15 \pm 1.0$ \\
\cline { 2 - 3 } & $10^{-4}$ & $21 \pm 2.3$ \\
\hline o-Phenanthroline & $10^{-3}$ & $85 \pm 2.3$ \\
\hline Dithiothreitol & $10^{-3}$ & $105 \pm 3.4$ \\
\hline L-Cysteine & $10^{-3}$ & $95 \pm 4.8$ \\
\hline$\beta$ - Mercaptoethanol & $10^{-3}$ & $96 \pm 4.5$ \\
\hline Sodium azide & $10^{-3}$ & $100 \pm 5.2$ \\
\hline Sodium arsenite & $10^{-3}$ & $87 \pm 5.0$ \\
\hline Sodium sulfite & $10^{-3}$ & $40 \pm 4.1$ \\
\hline $\mathbf{A g}^{+}$ & $10^{-3}$ & $5 \pm 0.1$ \\
\hline $\mathbf{H g}^{+2}$ & $10^{-3}$ & $5 \pm 0.1$ \\
\hline
\end{tabular}

Exposition time $-60 \mathrm{~min}$

Examination of the effect of other chemical agents showed that $\alpha$-galactosidase reaction was inhibited by $p$-chloromercuribenzoate and by the cations of silver and mercury. The analysis of the kinetic curves by Lineweaver-Burk procedure for $\alpha$-galactosidase inhibition by these reagents suggests that their action is a noncompetitive. The inhibition constants constituted $\mathrm{K}_{\mathrm{i}} 1.8 \times 10^{-4} \mathrm{M}$ for $\mathrm{p}$-chloromercuribenzoate, $\mathrm{K}_{\mathrm{i}} 2.5 \times 10^{-4} \mathrm{M}$ for silver, $\mathrm{K}_{\mathrm{i}} 4.5 \times 10^{-6} \mathrm{M}$ for mercury. Taking into account the absence of $\mathrm{D}-$ galactose protective effect towards the enzyme molecule (Fig. 5), as well as the findings concerning the reactivation kinetics with thiolic reagents (Fig. 6), one can be suggest presence of $\mathrm{SH}$-groups within the enzyme molecule, but not in its active center. These groups do not appear to be involved in the catalytic action, however they are important for $\alpha$-galactosidase activity realization, since they might act as additional bonds necessary for orientation and binding appropriately the substrate molecules in the enzyme active center. In this way they could specificity $\alpha$-galactosidase effect. It should be noted that $\alpha-\mathrm{N}$-galactosaminidase activity was not affected by these agents. Both $\alpha$-galactosidase and $\alpha-\mathrm{N}$-galactosaminidase activities were inhibited with sodium sulphite, which were also known to interact with $\mathrm{SH}$-groups. The compounds containing closely arranged 


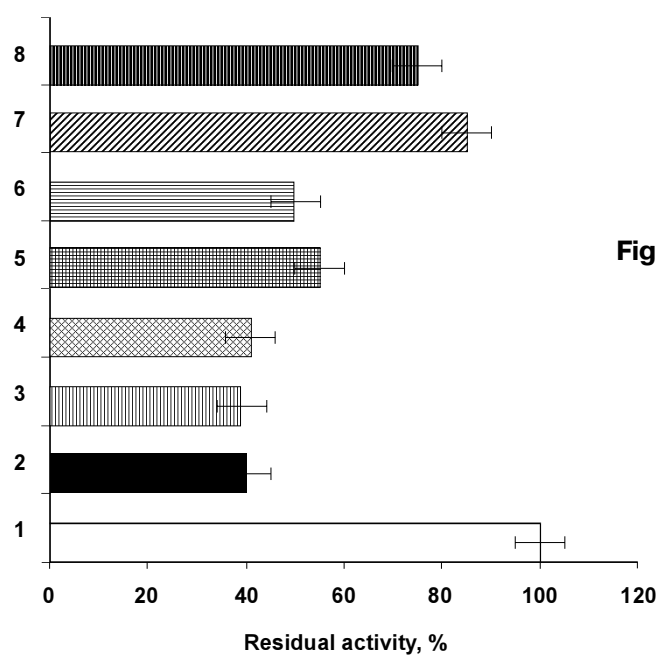

Fig 5. Effect of $D$-galactose and L-cysteine on the $\alpha$-galactosidase from A. niger 185 modified by silver ions.

1 - control (without inhibitor);

$2-\mathrm{AgNO}_{3}, 5 \times 10^{-4-} \mathrm{M}$;

$3-\mathrm{AgNO}_{3}, 5 \times 10^{-4-} \mathrm{M}+5 \mathrm{MM}$ D-galactose $(10 \mathrm{~min})^{*}$;

4 - $\mathrm{AgNO}_{3}, 5 \times 10^{-4-} \mathrm{M}+5 \mathrm{MM} \mathrm{D}$-galactose $(30 \mathrm{~min})^{\star *}$;

$5-\mathrm{AgNO}_{3}, 5 \times 10^{-4-} \mathrm{M}+1 \mathrm{MM}$ L-cysteine $(10 \mathrm{~min})^{*}$;

6 - $\mathrm{AgNO}_{3}, 5 \times 10^{-4-} \mathrm{M}+5 \mathrm{MM}$ L-cysteine $(10 \mathrm{~min})^{*}$;

$7-\mathrm{AgNO}_{3}, 5 \times 10^{-4-} \mathrm{M}+1 \mathrm{MM} \mathrm{L}$-cysteine $(30 \mathrm{~min})^{\star *}$;

$8-\mathrm{AgNO}_{3}, 5 \times 10^{-4-} \mathrm{M}+5 \mathrm{MM} \mathrm{L}$-cysteine $(30 \mathrm{~min})^{\star \star}$

* - preincubation

** - after incubation

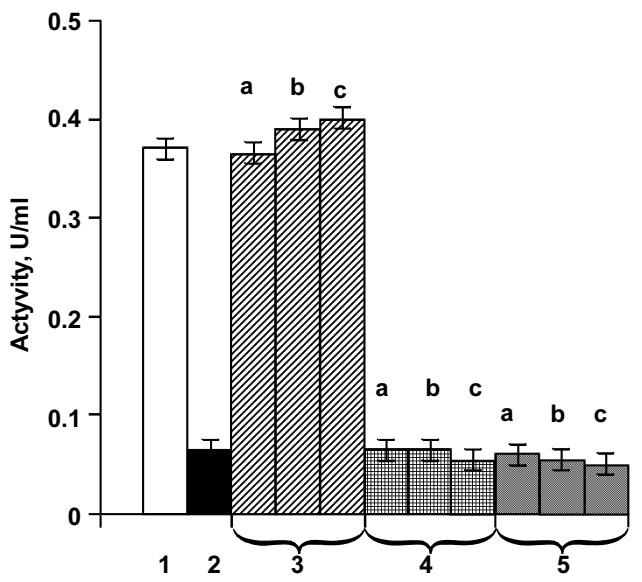

Fig. 6. Reactivation of $\alpha$-galactosidase from $A$. niger by the thiolic reagents after treatment with $p$-chloromercuribenzoate ( $p$-CMB).

1 - without inhibitor;

$2-10^{-4} \mathrm{M} \mathrm{p}-\mathrm{CMB}$;

$3-10^{-4} \mathrm{M} \mathrm{p}-\mathrm{CMB}+$ dithiothreitol;

$4-10^{-4} \mathrm{M} \mathrm{p}-\mathrm{CMB}+\mathrm{L}$-cysteine;

$5-10^{-4} \mathrm{M} \mathrm{p}-\mathrm{CMB}+\beta$-mercaptoethanol.

Concentration of thiolic reagents:

a) $10^{-3} \mathrm{M}$; b) $2 \times 10^{-3} \mathrm{M}$; c) $4 \times 10^{-3} \mathrm{M}$

$\mathrm{SH}$-groups (dithiols) are distinguished by high affinity to sodium arcenite which can be used for forming cyclic dithioarsenits. We found that in concentration $10^{-3} \mathrm{M}$ the arsenite only slightly affected the enzyme activity (Table 4). This finding suggests that within the nearest SH-group surrounding important for appearence of the $\alpha$-galactosidase activity, other neighbouring sulfhydrilic groups are lacking.

\section{CONCLUSION}

Our results suggest that catalytically active groups within $\alpha$-galactosidase isolated from $A$. niger 185 may include carboxylic group of C-terminal aminoacid (possibly asparagine or glutamine), as well as imidazole group of histidine. In addition, at some distance from the active center there may be present the SH-groups. They do not seem to be immediately involved in catalysis, but they are necessary for realization of $\alpha$-galactosidase activity. They also appear to be nonessential for the expression of $\alpha-\mathrm{N}$-acetylgalactosaminidase activity of enzyme under study. 
1. Albershein P., Nevis D.J., English P.D., Karr A. A method of analysis of sugars in plant cell wall polysaccharides by gas-liquid chromatography. Carbohydr. Res, 1976; 5 (3): 340-345.

2. Ananichev A.V., Ulezlo E.V., Zaprometova O.M., Bezborodov A.M. Some properties of immobilizated $\alpha$-galactosidase from Cephalosporium acremonium 237. Applied Chemistry and Microbiology, 1987; 23 (4): 552-557.

3. Andrews $P$. Estimation of the molecular weights of proteins by Sephadex gelfiltration. Biochem. J, 1964; 91 (2): 222-233.

4. Buglova T.T., Malanchuk V.M., Zakharova I.Ya., e. a. Isolation, purification and some properties of fungal $\alpha$-galactosidase. Microbiological Journal (Ukrainian), 1995; 57 (1): 43-48.

5. Chaplin M.E., Kennedy J.E. Carbohydrate Analysis. Oxford; Washington: IRL Press, 1986. 228 p.

6. Civas A., Eberhard R., Dizet P., Ze Petek F. Glycosidases induced in Aspergillus tamarii. Selected $\alpha$-D-galactosidase and $\alpha$-mannanase. Biochem. J, 1984; 219 (3): 857-863.

7. Dey D.F. Malhotra O.P. Kinetic behavior of sweet almound $\alpha$-galactosidase. Biochem. Biophys. Acta, 1965; 185 (2): 402-408.

8. Dey D.F., Pridham J. B., Sumar N. Multiple forms of Vicia faba $\alpha$-galactosidases and their relationships. Phytochemistry, 1982; 21 (9): 2195-2199.

9. Dixon M., Webb L. Enzyme. Moscow: Mir, 1982. 235 p.

10. Dubois M., Gilles K.A., Hamilton J.K., e. a. Colorimeric method for determination of sugars and related substances. Anal. Chem, 1956; 8 (3): 350-356.

11. Edsall J., Neuruth H., Walley K., e. a. Proteins. New-York: Acad. Press, 1958. $990 \mathrm{p}$.

12. Kornish-Bouden E. The Basis of Enzymatic Kinetics. Moscow: Mir, 1979. 280 p.

13. Kubo S. Glycosidases from soil microorganisms. J. Forensic Sci, 1989; 34 (1): 96-104.

14. Kurganov B.I., Petushkova E.B. Analysis of bell-like pH-dependences of enzyme reaction rate. Biochemistry, 1992; 57 (3): 348-361.

15. Laemmli U.K. Cleavage of proteins during the assembly of the head of bacteriophage T4. Nature, 1970; 227: 680-685.

16. Lowry O.H., Rosebrough N.J., Farr A.L, Randall R.J. Protein measurement with folinphenol reagent. J. Biol. Chem, 1951; 193 (2): 265-275.

17. Neustroev K.N., Krilov A.S., Abroskina O.N., e. a. Isolation and properties of $\alpha-$ galactosidase from Aspergillus awamori. Biochemistry, 1991; 56 (3): 447-457.

18. Petrova I.S., Vinzyunajte M.H. Applied Biochemistry and Microbiology, 1966; 2 (1): 322-327.

19. Severin S. E., Solovyeva G.A. Manuals in Biochemistry. MSU, 1989. 509 p.

20. Somogy M. Notes on Sugar Determination. J. Biol. Chem, 1952; 195 (1): 19-23.

21. Ulezlo E.V., Zaprometova O.M. $\alpha$-Galactosidase of microorganisms. Applied Biochemistry and Microbiology, 1982; 18 (1): 3-15.

22. Vidershine G.Ya. Biochemical Fundamentals of Glycosides. Moscow: Mir, 1980. 239 p.

23. Yan Z., Zhu Q., Shu M., e. a. Purification and properties of $\alpha$-galactosidase from Absidia ramose. Acta Microbiol. Sin, 1989; 29 (4): 265-271. 